\title{
IS THERE A REASON FOR THE EXISTENCE OF AN INDEPENDENT FINNO-UGRIC MUSICOLOGY?
}

\section{A COGNITIVE APPROACH TO THE COMPOUND NATURE OF FINNO-UGRIC MUSIC CULTURES}

\section{György Kádár}

The "task" of a musician, a composer or a performer is to create the composition. Then, the audience may, or may not be able to feel, or identify with the piece. Should the audience be able to feel with it, the piece is successful: a musical, artistic experience is born. The musician on the other hand, does not only want to feel, but rather understand how music, art is born. Of course, this, does not free him / her of getting to know the pieces on the level of enjoyment. (I must point this out, for unfortunately there are many musicians, who research music only based on sense.)

Nowadays in science, it is a generally accepted requirement that every researcher shall inspect the phenomena in their own system. For a Finno-Ugrian musician researching the music of Finno-Ugrians should, first of all, think over whether there are such specialities of musical culture of this ethnic group that differ from other ethnical groups; does the nature of the researched musical piece differ from the musical culture of other European groups' musical culture. If so, is it necessary to develop a new conceptual system, a new methodology - differing from the musical research system, method of other European nations' - or perhaps not? For, should the researcher not ask these questions, then he or she may address these musical pieces with other measures, and will never understand their essence or depth.

Reviewing the history of musical research, we may say that considering the essence of these questions, they are - ever since romanticism still out in the open.

Yet, the new approach, the new ways of questioning of the cognitive sciences demand answers for these questions: how does a person speaking one of the Finno-Ugrian languages conceive musical phe- 
nomena: how does he or she approaches them, how does he or she understand them, and create musical "texts", does he or she approach music differently than representatives of other linguistic groups, what is his or her conceptual system of his or her own group's music, musical experiences, does his or her musical thinking differ from that of other ethnic groups, is there a relationship between music and linguistics, musical-relationship exists, that may help us to understand the unique features of the musical culture of different nations?

The new approaches, the new methods and ways of questioning and answering questions of cognitive musical science may open up new perspectives to researchers, and may establish the basis of a standalone Finno-Ugrian musicology in the line of the newly created comparative Finno-Ugrian musicology.

In the following I will touch upon the above topics.

\section{CONFRONTATION OF DIFFERENT EAST-EUROPEAN MUSICAL CULTURES - A SHORT HISTORICAL OVERVIEW}

During Romanticism the idea of an international musical culture was common all over Europe. This theory held true until the EastEuropean peoples slowly started to awake from the cultural colonisation and introduce their unique musical pieces that differed from the other nations often quite considerably (like the Russian composers Glinka and Mussorskij, the Finnish Sibelius, the Romanian Enescu, and last but not least Bartók and Kodály, etc). At first, these musical pieces seemed nothing more than "a sweet cluster of grapes squeezed into new wine" (ADY, Endre), but gradually it was learned that although their language structure may not always be the same, these music pieces are able to express the fluctuation of similar human emotions (Langer 1953, 1957).

M. A. Castren, for example, who grew up in German musical culture, and can thus hardly be accused of hostile feelings towards our kindred nations, wrote of the tunes of the Samoyeds in 1848: 
At weddings, girls are singing. Looking at their meaning, they are beautiful, but their tunes are like frog-croak. (Castrén 1853: 219)

Those who can not understand the language structure of the music of East-Europe, can not understand Bartók's music either (and neither his way of thinking, we may presume).
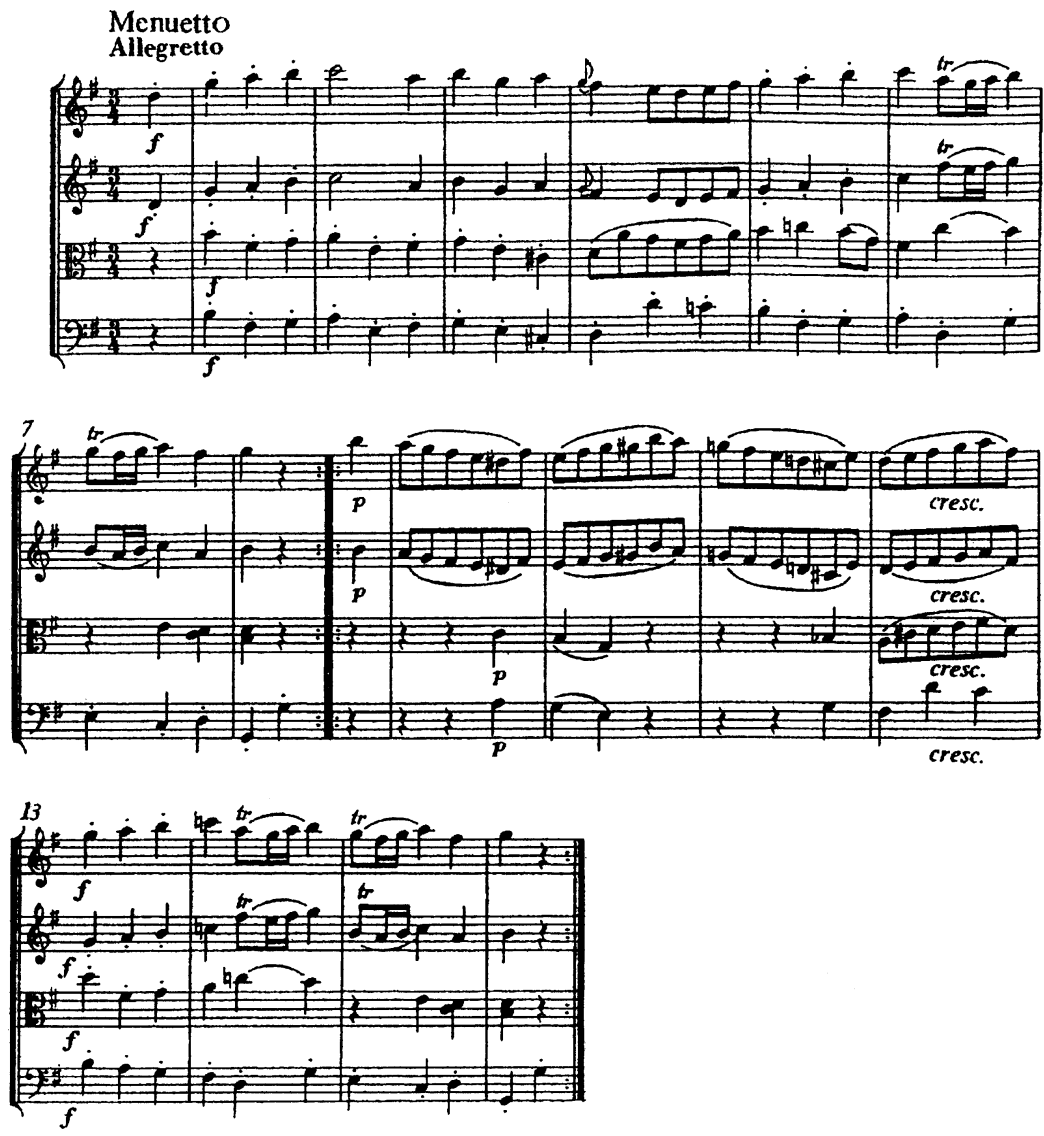

Notes 1: Mozart: Night Music 
And then Bartók became the prisoner of foreign spirit. [---] Deux images [Two pictures]. A chaotic mixture of sounds, on top of which, no theme is floating. [---] Brutally raw colours, crackling rhythm, a fussy dynamics, resembling that of Strauss can be heard. The adoption is way behind that of the paraphrases of the slaves and the Scandinavians. (Budapesti Hírlap, 27.02.1913)

The critic may have evaluated Bartók's music somewhat negative, but has pointed out the essence of it. The most important thing is, that Bartók "became the prisoner of foreign spirit". And has pointed out one of the important features of Finno-Ugrian music: "on top of which, no theme is floating". Should we compare, with German ear, ${ }^{1}$ the pieces of Bartók with Mozart or from Palestrin, through Monteverdi, to the above-mentioned Strauss, the critic is still right.

Bartók's Allegro Barbaro is of course full of "brutally raw colours" with, "crackling rhythm", and "on top of which, no theme is floating."
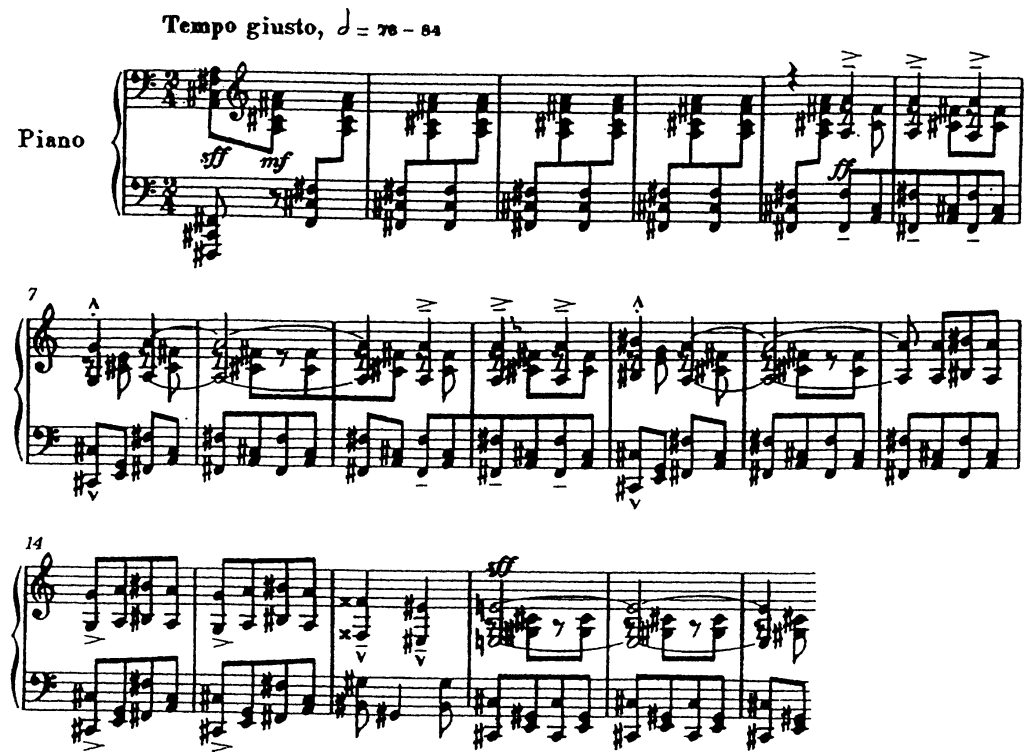

Notes 2: Bartók: Allegro Barbaro 
I could give many examples on how someone growing up on WestEuropean music, expects something from the Samoyed songs, or from Bartók's music, that is not present in there. This is nothing else than ("spirits foreign to each other") the encounter of two different musical cultures.

\section{ON WHAT SUB-AREAS DO FINNO-UGRIAN AND WEST- EUROPEAN MUSICAL CULTURES DIFFER?}

The basis for Finno-Ugrian comparative musical science, and also the cognitive inspection of Finno-Ugrian musical cultures, was established by Gábor Lüko, who was able to separate the ancient layers and characteristics of these and other (ancient Slavic, ancient Indo-European) cultures (Lüko 1962, 1964, 1965). As it turned out, the musical language of these cultures differs not only because of the difference in their scale, but the association structure of the sounds within the scales differs as well (Kádár 1994: 49-70). (This has been used to explain the intervals - like septims -, that are considered dissonance by the West-Europeans, and as consonance in these musical cultures, not requiring a dissolution, as explained by Bartók in his own method of composing. At this point Bartók and Lüko have become the precursors of cognitive musical science.)

Later on, it became evident that these cultures may have a different understanding of different musical concepts. The most important may be that defining musical sounds in the scale of "high-low" is totally unknown among the uneducated parts of Finno-Ugrians. They define the quality of sounds for themselves as "thick-thin" (Nykysuomen sanakirja IV: 18, 178). Even Döbrentei speaks of thick and thin vowels in his grammar book (Döbrentei 1832). And this is not all. If they were able to associate the "thick-thin" concept of the Hungarians with the "high" and "low" concepts, then "thick" will be above, while "thin" will be below. That is the other way around as in their accustomed musical writing structure (Luby 1942). At the same time, the Finnish psaltery (kantele) player holds his instrument the same way in his lap: that is, the longer thick chords are on the bottom, while the shorter thinner ones are on the top. If we took the cognitive sciences serious, then these observations would have "serious" consequences in our writing structure. 
The most important difference of Finno-Ugrian musical cultures, compared to other music cultures, is their compound structure.

\section{COMPOUND THINKING - THE MOST IMPORTANT CHARACTERISTIC OF FINNO-UGRIAN MUSICAL CULTURES}

\subsection{Defining compound thinking}

The importance of compound sentences and words, as well as the unique speciality of these languages has been emphasised in FinnoUgric researches for a long time. The fact, that this imbibes a whole way of thinking was first pointed out by Sándor Karácsony, speaking about the Hungarian language.

Should we be able to forget, if only for a moment, what we have thought about Indo-German language sciences, and be able to accept without bias the facts of the Hungarian language as they appear - not knowing anything about Grammatik terminologies, systems, categories and definitions -, the language itself would show its inner laws as the fruits of its productive theory. Well, this power network, that should appear this way, would be the compound. Should we reduce every phenomenon to a common law, that law would sound that the grammar of the Hungarian language is not oriented towards combining all the conceptual signs in one concept, but rather indicating by comparison two concepts, or a concept and a relation, or two relations. So in the sign-structure, subordination always abstracts, while compounding demonstrates. This difference exists even in the meaning of the word. An Indo-Germanic word always marks with some sort of generality, or difference, while the sign of the Hungarian word is what it is compared to something. (Karácsony 1985: 253)

\subsection{The subordinating way of thinking in the conceptual structure of the Finno-Ugrian languages}

How subordination appears in the conceptual structure of people, speaking a Finno-Ugrian language? Can Karácsony's observations be proved or applied to others speaking Finno-Ugrian languages, too? 
The Finno-Ugrian people, in their verbal thinking have only one thing in common; the approach toward another person. FinnoUgrians are not pronouns defined abstract entities (die Mutter, der Vater, das M, etc.), rather a part of their fellow-being. Only compared to another fellow-being is a Finno-Ugrian a human. This absrtact is completely different from that of Indo-German cultures.

Here, I would like to only demonstrate this with examples from the Finnish and Hungarian languages:

puolisonsa - feleség - his wife (in Finnish, 'a spouse')

házas-felek - married partners ${ }^{2}$

puolisko(nsa) - fele - half of / partner to

osapuol(ensa) - ügyfele - client to (partner in business)

riitapuolet - peres fele - contestant to (partners in a law-suit)

hyökkäävä puoli - támadó fele - aggressor (one of two fighters)

äitipuoli - féltestvére - half-brother to / half-sister to

puoltaa - megvédelmez - protects

puoltaja - felelo - responder, replier

vastata - felel (< Hung. felel 'to give half') - to respond

(In case of nouns, the personal suffix is a must.)

(Based on historical phonetics, the Finnish puoli is an exact match to the Hungarian fél 'part of, partner, half'. The Hungarian equivalent of the Finnish initial letter $p$ - is always the letter $f$-; while the middle - $l$ - stayed the same in both languages. So, based on the above, linguists assume that the word, noting a lingual philosophy that without a pair speaks of a person as a "semi-person", is at least 5,000 years old.)

That is, a Finno-Ugrian - talking with his / her partner - is not forcing his / her autonomy to his / her partner, rather - at least based on their language - giving up his / her own "part of" autonomy accepts the other person as a partner in the conversation. This might be a reason for the Finno-Ugrians answer to a question with a single yes or no only on a special occasion. Finnish translators, translating TV-programs correctly avoid the abstracting "Yes" of English. 
Megértette, amit mondtam? - Meg(értettem). [And not: igen] Did you understand what I said? - I understood. [And not: "yes"]

Kävitkö eilen kahvilassa? - Kävin, mutta vasta illemmalla. [And not: Kyllä.]

Were you at the Café yesterday? - I was, but only in the evening. [And not "Yes".]

Knowing this, it can not be a coincidence that Gabriel Porthan, in his work "On Finnish Poetry" (Suomalaisesta runoudesta), reports that Finnish people call the odd-lines 'leader' (pä̈̈mies ) and the even lines 'replier, advocate' (puoltaja; puoltaa 'to give half') of their songs sang in rotation, called Kalevalan songs (vuorolaulu) ${ }^{3}$ (Porthan 1983: 79).

\subsection{The compound thinking in the Finno-Ugrian language and poetry}

Below, I will introduce some characteristic examples for the compound thinking that should be familiar to any Finno-Ugrian specialist.

On the word level:

(Vogul) elum-holum - 'living-dying', 'person'

(Finnish) maa-ilma - 'ground-sky', 'world'

(Hungarian) testvér - 'brother/sister', 'sibling'

(Vogul) ujhul - 'animal-fish', 'animal'

(Hungarian) arc - 'nose-mouth'

(Vogul) agipig - 'girl-boy', 'child'

In verbal structure:

(Finnish) silmänä korvana - 'as eyes and ears', 'observing /watchful'

(Hungarian) fut-fát - 'grass-and-trees', also 'promises wonders' (Finnish) puutaheinää - 'grass-and-trees'

(Hungarian) árkon-bokron - 'trench-and-bush', also 'head over heels'

In clauses: 
Finnish

lapsi on tuotu laulajaksi, The child was brought for singer, poika kunnon kukkujaksi. To cook the cuckoo-boy. (Kalevala 20, 541-542)

Jo täällä tämänki talven, Here is the winter, jopa mennehen kesosen [---] Here is the last summer [---] (Kalevala 25, 179-180)

Tulit pääni polkemahan, You've come to smash my head, Aivoni alentamahan! (Kalevala 27, 75-76) to decry my knowledge.

Vogul

Rightful for the animal girl low voice noise they whoop my three whoops, thin voice noise they whoop my four whoops. (Munkácsi 1893: 316)

The lord of the town, took a five stringed wood to his hands. Plonks the bottom chord:

Calls the winged Gods over, Plonks the top chord:

Calls the legged Gods over. (Munkácsi 1893: 537)

I must emphasise that the examples above are only the surface. People speaking Finno-Ugrian languages, in general and on every level of the language, like to express things in relation to something else. It is not our task here to introduce this structure - I just simply point out that the rich personal - and correlating conjugation structure of the Finno-Ugrian languages is probably the result of this strong "will" of correlating. I also add as a remark that contrastive researchers should research on the extinction of the rich personal conjugation structure of modern Finnish language, which is most likely the result of the abstracting of personal relationship. (This is partly the reason why Finnish grammar is strongly being revised nowadays.) 


\section{The compound way of thinking in the Finno-Ugrian music}

The musical compound structure - as far as I know - was first mentioned by Kodály (Kodály 1969: 37). His understanding was that parallelism can be discovered in the lines of Hungarian folk-songs. László Vikár observes the same phenomenon, when noting that Finno-Ugrian folk songs are single seeded. Erkki Pekkilä in his musicological research, independent of Kodályt and Karácsony discovered two musical building structures (Pekkilä 1988: 157-158). The paratactic (= compound) and the hypotactic (=subordinate). According to him, paratactic structures can be identified by the fact that their segments are reversible, while these of the hypotactic are not. Just like in language:

When in Kalevala the Heroes are afraid or in danger, they formulate the question, using the below structure:

Miten olla, kuin eleä How shall we be, how do we live

This can be reversed, like this:

Kuin eleä, miten olla I will be so long as I live.

Or with an example from Kanteleta:

Pääskyläinen, päivänlintu, päivänlintu yönlipakko

Swallow of all, bird of sun, bird of sun, fowl of night

can be reversed:

päivänlintu, pääskyläinen, päivänlintu yönlipakko

Bird of sun, Swallow of all, bird of sun, fowl of night

The same applies for music. (To keep it simple, I will only introduce eight syllable examples). Our third note example is a lullaby from Uhtua:

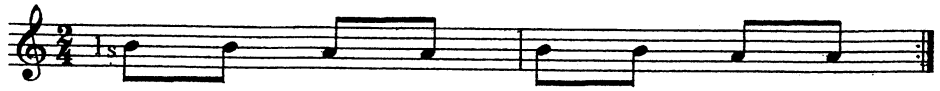

Notes 3. Krasnopolskaia 1977: 12. 
The notes are arranged to pairs and move combined. These notepairs are reversible, and it follows the same musical structure.

The next tune was recorded from Setu (a small Estonian ethnic group):

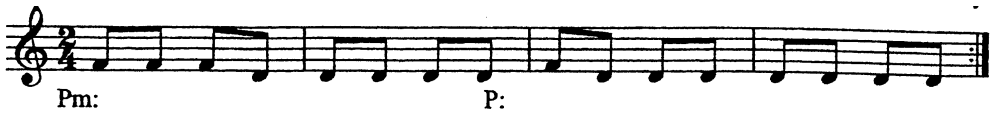

Notes 4. Salve 1987.

Reversing the note pairs here would not make the musical structure uninterpretable either.

The same applies for the next two examples:

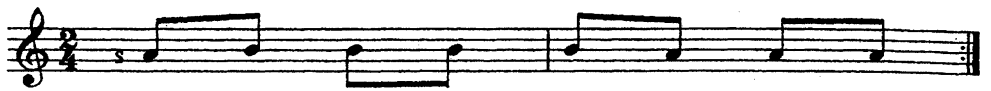

Notes 5. SKSÄVIV/150.

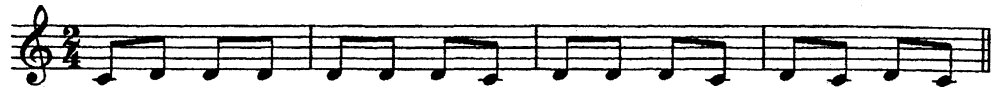

Notes 6. Väisänen 1937: 146 .

We may change the order of the lines within the line pairs:

la-la-la-so, la-so-la-so - so-la-la-la, la-la-la-so.

Not all Finno-Ugrian musical examples are this simple, but it is also true for the more complexes ones, that there is no subordination. Therefore, if we were to create a computer program that would generate Finno-Ugrian music, it would have a pretty simple algorithm. The example given here is limited to sounds that are of two seconds' distance from each other, where $a$ is the initial sound, while $b$ is the possible next, at one second distance (using standard logical symbols): 
1. line (beatpair)

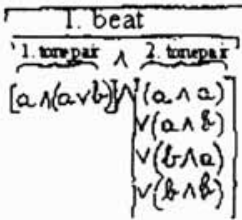

A week I spent at kept poor captive

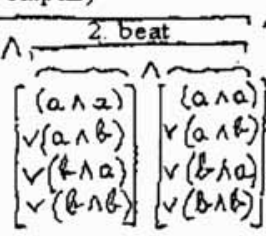

mummy's home, an moaning, whining,
2. line (beatpair)

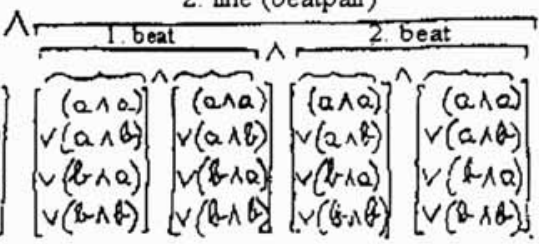

other one with being guest

kept bewailing her lot

Figure 1. Kuusi 1980: 107, 79.

This formula can only be extended with a few Finno-Ugrian musical rules (some popular reflecting methods, for example).

Another algorithm should create rhythm, which results (following a few statistical check-ups) could be applied without any extra rules on the results of the previous algorithm. For creating rhythm we should only define what rhythmical values $a$ and $b$ possess. Should $a$ and $b$ have the same or different values, and should these be quavers or crotchets (or 1:1/2s).

The below examples are from different Finno-Ugrian cultures:

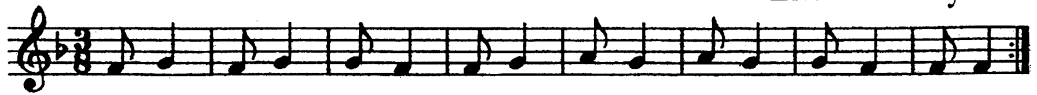

$$
\text { Sot-ka - lin-tu suo-ra lin-tu sot-ka - lin-tu suo-ra lin-tu }
$$

Notes 7. Tedre 1975: 2.

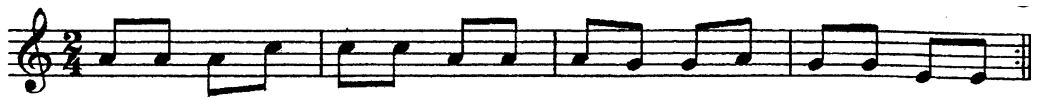

Notes 8. Lázár 1996: 39.

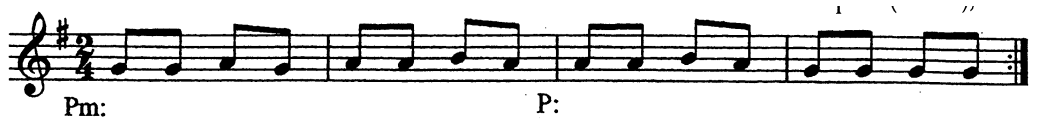

Notes 9. SKSÄV IV/2: 138.

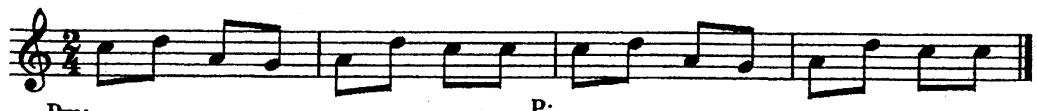

Pm:

Notes 10. SKSÄV IV/1: 109 . 
In the three examples, collected at Soikkola (on the territory of Finland), built on three notes, mirroring takes place in the forth tune of the line.

From the examples it can be concluded that in compound music, the essence is in how the notes, note-pairs and lines relate to each other. Whether they are the same (aa), or the same with small changes $\left(\mathrm{aa}_{\mathrm{v}}\right)$, or the same with reflecting $\left(\mathrm{aa}_{\mathrm{t}}\right)$.

The following Hungarian examples show the same characteristics, but with a bigger ambit:

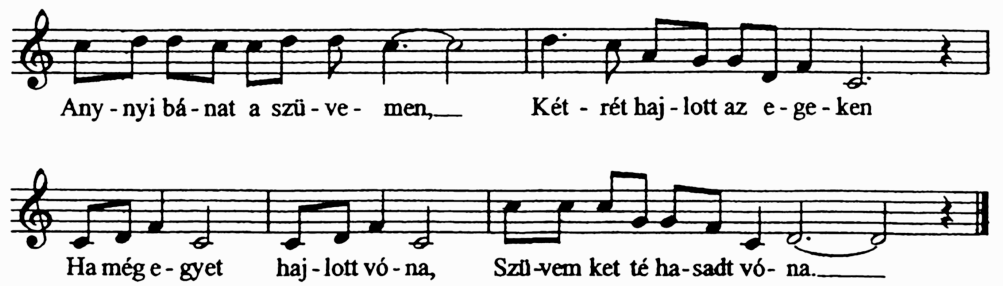

Notes 11. Bartók Eight Hungarian Folk Songs. (song-piano).
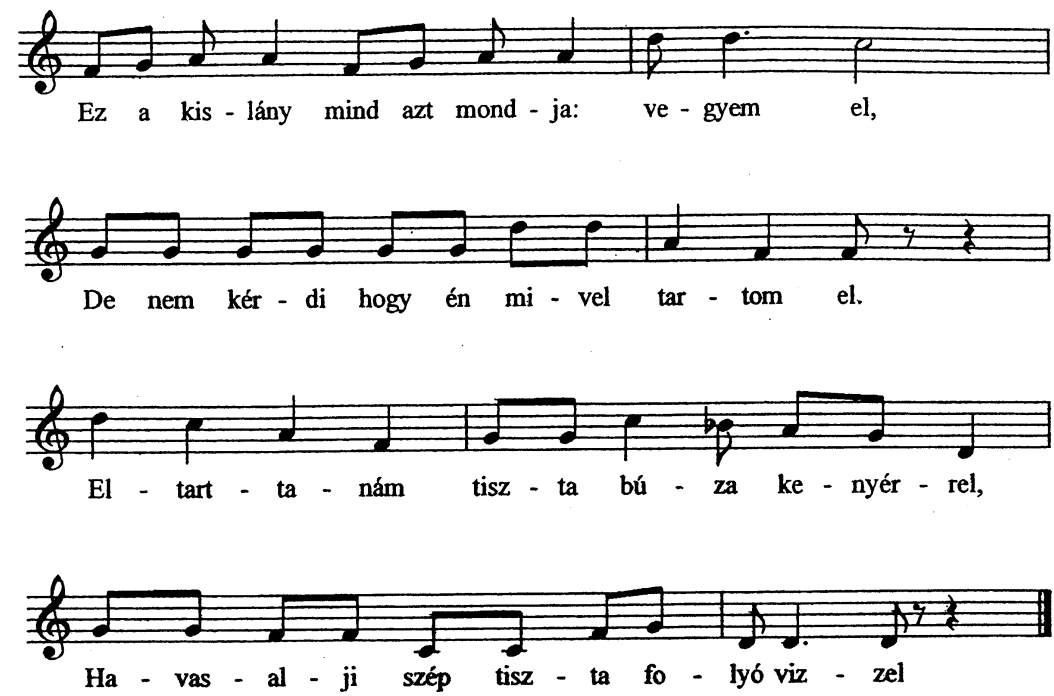

Notes 12. Bartók 1921: 100. 
In the following Cheremis tune, following the first beat - au contraire to Wiener music - we do not anticipate where the tune proceeds, but rather how the next beat interprets the first one. In other words, how the processing beat, not yet heard, will interpret the first one. And once we hear the first line, then the audience, familiar with Cheremis musical language, expects from this second line how it will interpret the first one. How the two parts will make a whole. The tunes of the first and the second line are the same, except in the second part: there is transpositional reflection:
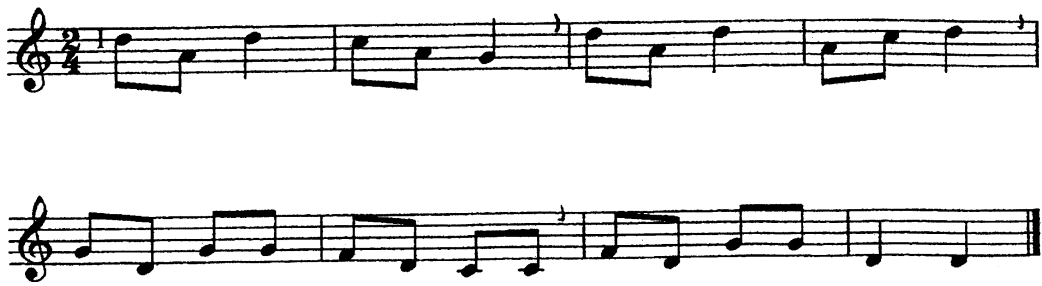

Notes 13. Vikár 1971: 251.

In the next example, we find reflection between the rhythm of the beats:
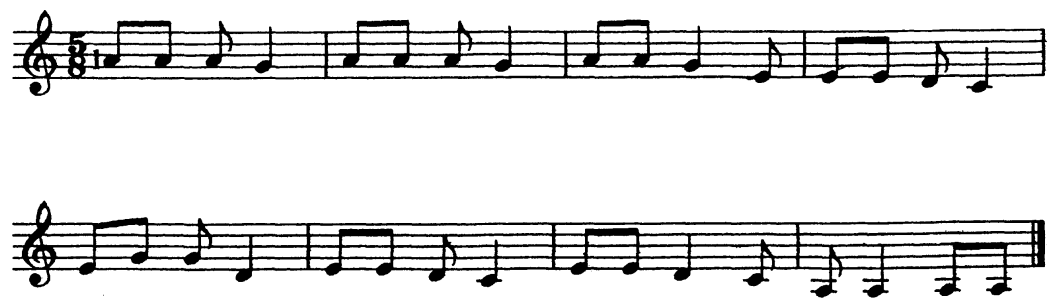

Notes 14. Kodály 1946: 21.

Same phenomenon, even neater, is displayed in Notes 15-16.

These phenomena or ways of thinking are present in the art of all composers (like Bartók, Kodály, Kostiainen, Tormis, etc), who acquired the thinking of the Finno-Ugrians. Bartók himself liked quartsound, of which he noted (as mentioned before), that it does not require dissolution (see Notes 17 ): 

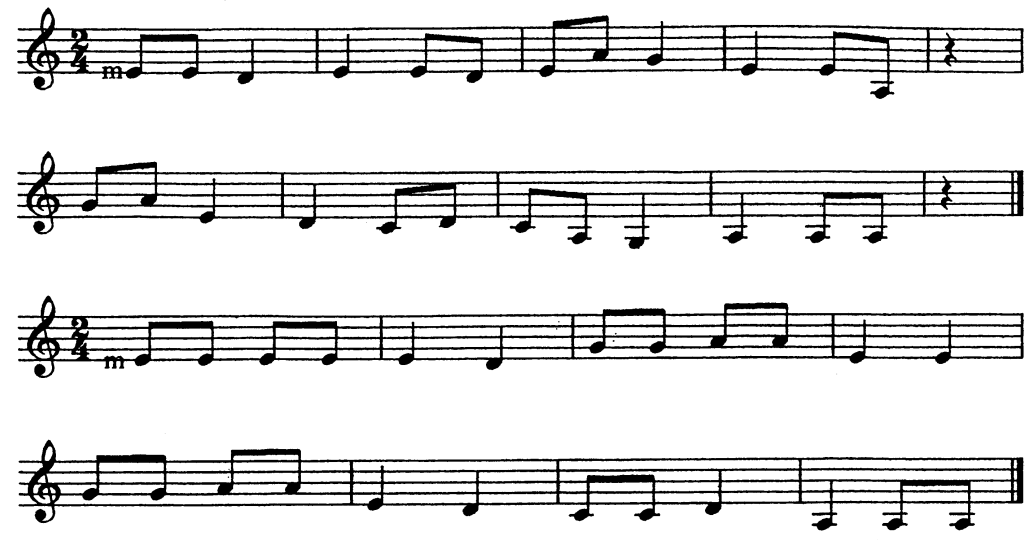

Notes 15 (Kodály 1946: 15) and 16 (Kodály 1946: 98).
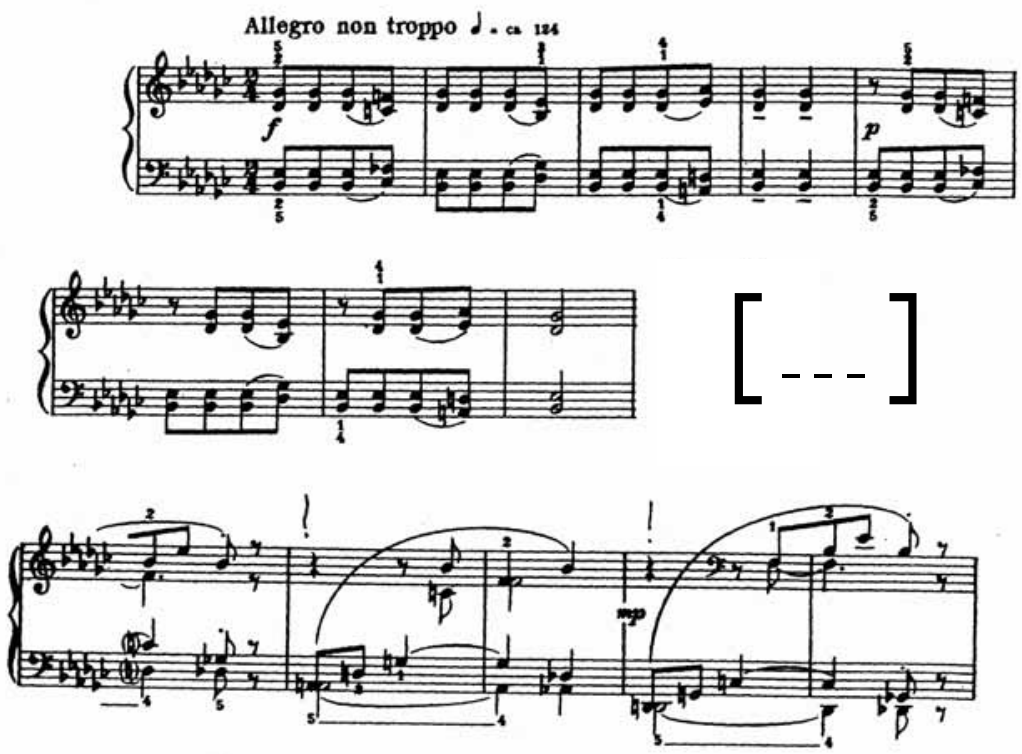

Notes 17. Bartók: Mikrokosmos 131. 
We may even change the musical segments (Pekkilä) and still leave the musical text will still sound logical. (We may change the first and second beat.)

In a Bartók's chorus piece, Loaf-baking, a very popular song among children, the quarts do not require a dissolving either, and can be interchanged. (Here, I would like to point out that the two crotchets at the end of the line are signs of the presence of a subordinate thinking.) (See Notes 18.)

It may appear that musical pieces composed this way would be too simple. At the same time, it is important to point out that compound thinking is hardly purely represented in them. As for me, I was trying to introduce pure examples here for easier understanding. In my previous studies, I noticed that these two conceptual ways of thinking (compound and subordinate) are present in a mix, rather than by themselves in these musical cultures. All we can state, is that in Finno-Ugrian cultures - like in the languages compound structure is preferred, and that these musical languages are rather compound-structured. Subordinate structures are well known in the Finnish language, too, but compound structure seems to be more "natural". And just to rule out the thought that compound-structured musical cultures are simple:

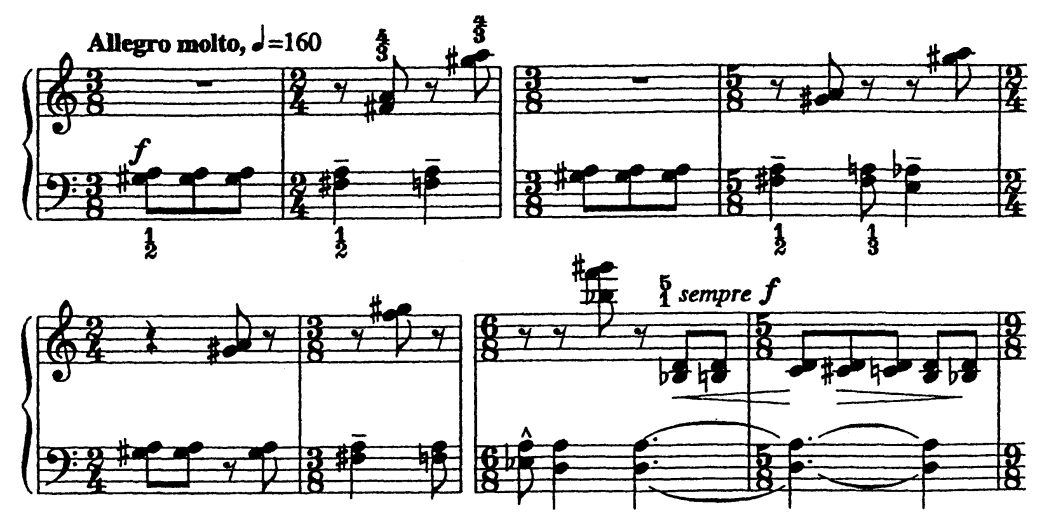

Notes 19. Bartók Mikrokosmos 140.

Interestingly, it was not foreign to Bartók and Kodály to make both parties sound. The ancient forms of these can be most clearly seen in the Finnish bisecting, or Kalevala songs (vuorolaulu) where the 


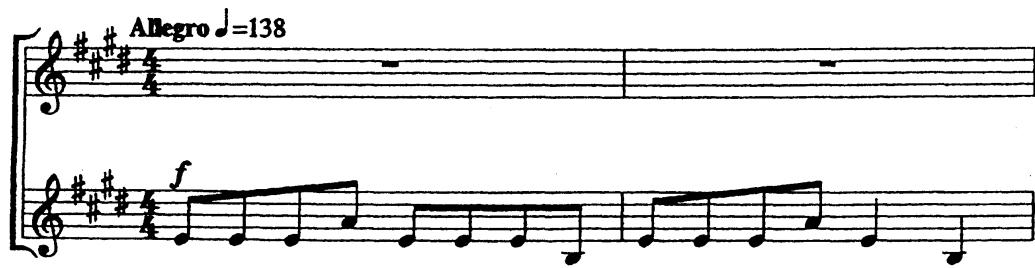

Ker-tem a - latt, ker-tem a - latt a - rat há-rom var - nyú,

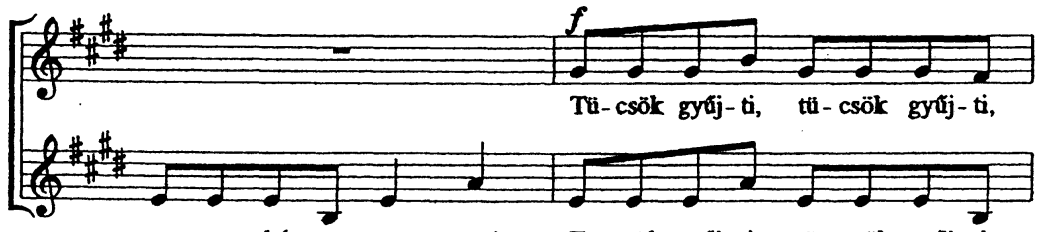

a - rat há-rom var - nyú; Tü-csök gyưj-ti, tii-csök gyứj-ti,
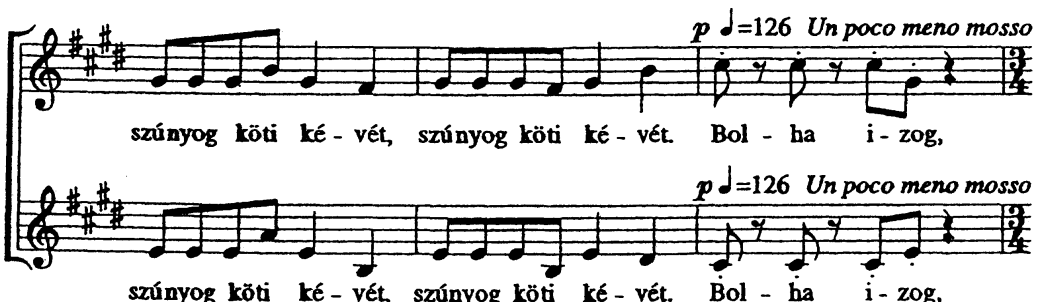

szúnyog kōti ké - vét, szúnyog köti ké - vét. Bol - ha i-zog,
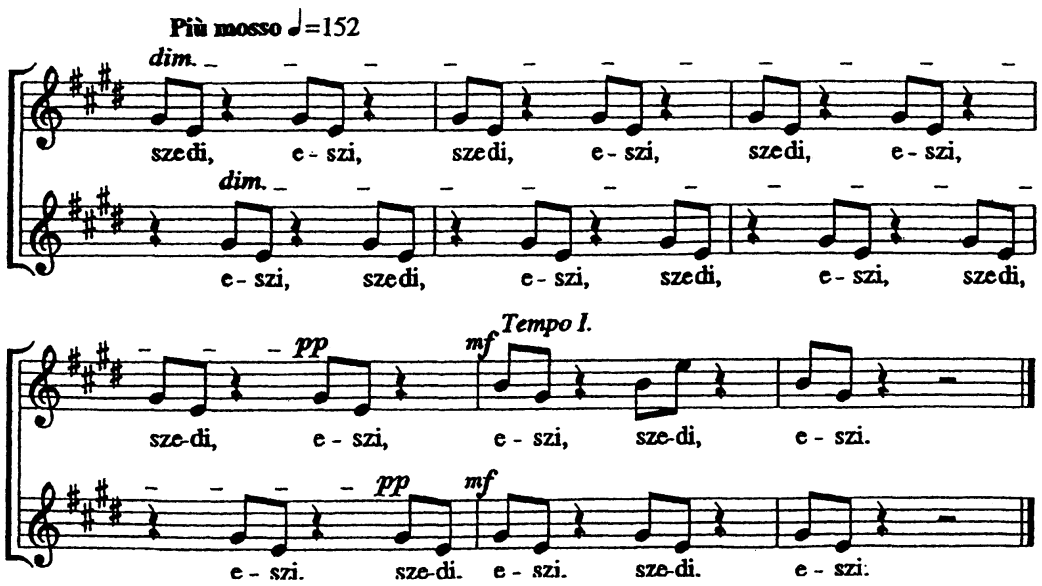

Notes 18. Bartók: Cipósütés. 
line-pairs are sung separately by the päämies and the puoltaja. In Kodály's Biciniums - perhaps in more than half of them - the first part of the tune is sung by the first chanter, while the second is sung by the second chanter. Just like in Bartók's Microcosmoses. Here, one part of the tune is played by the right hand, while the left hand plays the other. Even more interesting is that Bartók in his orchestra Music for the strings and the percussions divides the orchestra into two, and they perform the parts of the piece referring to each other as semi-sentences, in rotation:

1. V1.

Presto strepitoso, $d=210$

2. VI.

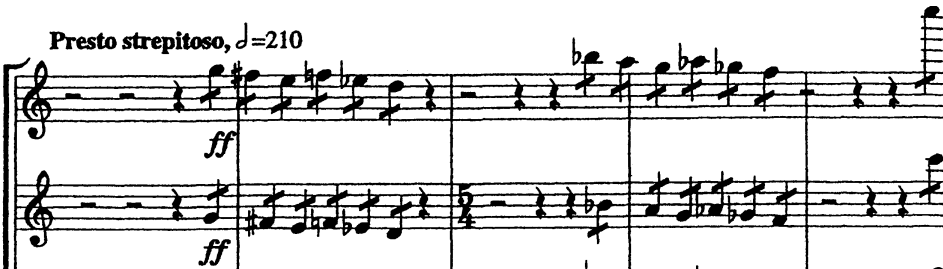

1. Vle.

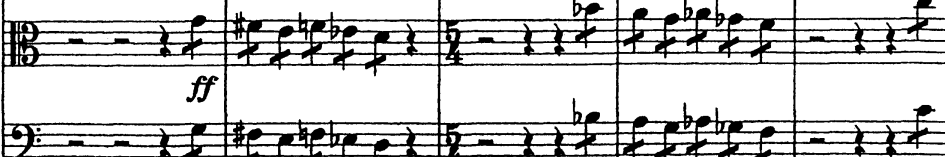

1. Vlc.

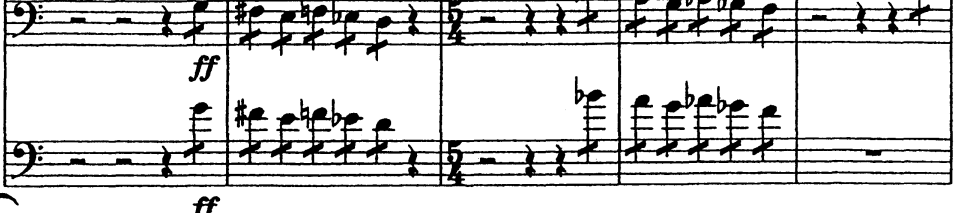

1. Cb.

ff

3. Vl.

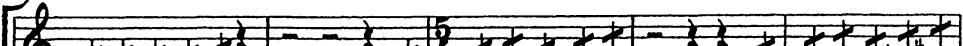

4. VI.

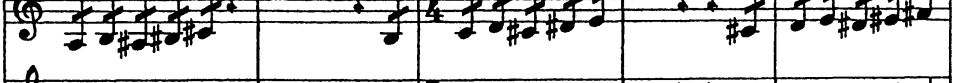

2. Vle.

2. Vle.

2. $\mathrm{Cb}$.

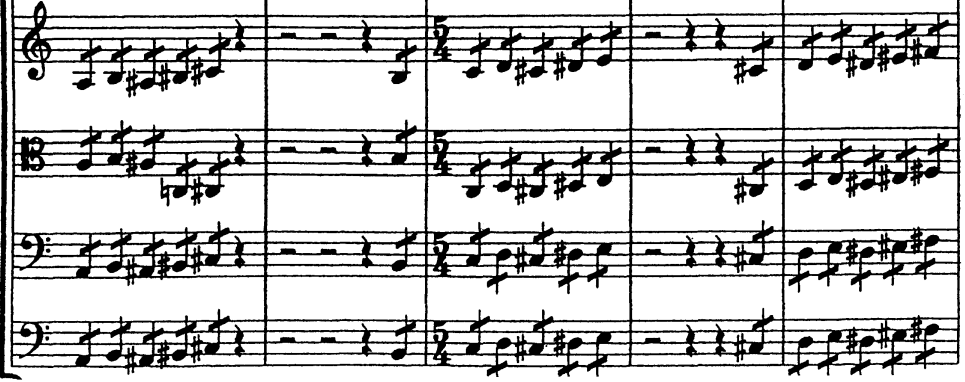

Notes 20. 
We may agree that the Bartók's critic was right, stating that "on top of which, no theme is floating." The problem is that in such musical thinking it doesn't even want to. In this musical thinking, the troubadour, or the composer is not interested in how the waves of the soul can be transferred into "more beautiful arcs" from the tonic to the sub-dominant, from there to the dominant and finally to the soothing tonic, rather how the sounds without almost any properties form pairs with each other (for a sound will only make sense through another sound - but I will not address this topic here due to lack of time), how the newly formed sound-pairs relate to each other, how the beat is formed from the relations of these soundpairs, from that, the beat pairs, and from those, the lines interpreting each other. How the compound sections for a whole. The person whose thinking is based on one of the Finno-Ugrian musical languages, expects this from the "text" of the music.

This is the "foreign spirit", or the "foreign" way of thinking and composing, that inspires Bartók's music. Like Allegro Barbaro, presented above. Those expecting a West-European subordinating music from this, will unfortunately be disappointed.

Vaasa, 5.10.2002

\section{Comments}

This article is the text of the lecture that was given at the Congress of Uralistic Faculty of Berzsenyi Dániel Teacher-training College, Szombathely, 2002.

1 Since the Wien play of Kodály's János Háry, we know how the music of Wien sounds for a Hungarian (or Easter) ear.

2 Literally, Fi. puoli and Hung. fele mean 'half'.

${ }^{3}$ Traditionally, Finnish mythical songs, heroic songs and other songs were sung as vuoro-songs, sung by changing singers. The main singer started with a line to which the other singers (Finnish: puoltaja) replied (the word reply must be emphasized here), then came the main singer again with another line, which, once again, was replied. And they proceeded this way throughout the song. 


\section{References}

Bartók, Béla \& Kodály, Zoltán 1921. Erdélyi magyar népdalok: Közzé teszik [Hungarian Folk Songs from Transylvania]. Budapest: Népies Irodalmi Társ.

Castrén, Matthias Alexander 1853. Reiseerinnerungen aus den Jahren 1838-1844. Hgg. von Franz Anton Schiefner. Nordische Reisen und Forschungen: Castrén 1. St. Petersburg: Eggers.

Döbrentei, Gábor 1832. A magyar helyesírás és szóragasztás fobb szabályai: A' Magyar Tudós Társaság' különös használatára [Hungarian Spelling]. Pesten.

Kádár, György 1999. Rinnasteinen ajattelutapa suomensukuisten kansojen musiikkiperinteessä [Paratactical thinking in the music tradition of Fenno-Ugrian people]. Jyväskylä studies in the arts 67. Jyväskylä: University of Jyväskylä.

Kádár, György 2002. Pentatonic patterns of Construction. - Asian Musicology, vol. 2. Korea. = Kádár, György 1995. Pentatonic patterns of Construction. - Fredrikson, Maija \& Sormunen, Anu (eds.). Pentatonism as a Phenomenon. Yearbook 1994. Jyväskylän yliopiston musiikkitieteen laitoksen julkaisusarja A: tutkielmia ja raportteja no 12. Jyväskylä: The Finnish Kodály Center.

Karácsony, Sándor 1985. A magyar észjárás [The Hungarian Way of Thinking]. Magyar hírmondó. Budapest: Magveto.

Kodály, Zoltán 1946. Ötfokú zene I: 100 magyar népdal [Five Scale Music part I: 100. Hungarian Folk Songs]. Budapest: Editio Musica.

Kodály, Zoltán 1969. A magyar népzene [Hungarian Folk Music]. Budapest: Zenemukiadó.

Krasnopolskaia, Tamara 1977. Pesni karel'skogo kraia [Songs of Kareliia district]. Petrozavodsk: Kareliia.

Kuusi, Matti 1980. Kalevalaista kertomarunoutta [Repetitive Songs in Kalevala]. Suomalaisen Kirjallisuuden Seuran toimituksia 362. Helsinki: Suomalaisen Kirjallisuuden Seura.

Langer, Susanne Katherina 1953. Feeling and Form: A Theory of Art: Developed from Philosophy in a New Key. Scribner library 122. New York: Scribner.

Langer, Susanne Katherina 1957. Problems of Art: Ten Philosophical Lectures. New York: Scribner.

Lázár, Katalin 1996. A keleti hantik vokális népzenéje [The Vocal Folk Music of the East-Hants]. Budapest: Népr. Múz.

Luby, Margit 1942. Fogyó legelokön [On Decreasing Fields]. Budapest.

Lüko, Gábor 1962. A pentaton hangrendszer [The Pentaton Musical Structure]. - Ethnographia: A Magyar Néprajzi Társaság folyóirata LXXIII. Budapest: Akadémiai Kiadó, pp. 277-301. 
Lüko, Gábor 1964. Zur Frage der Musikkultur in der Slawischen Urzeit. Studia Slavica Academiae Scientiarum Hungaricae = Studia Slavica Hungarica X: 3-4. Budapest: Akadémiai Kiadó, pp. 237-289.

Lüko, Gábor 1965. Vestiges indo-européens dans le folklore musical des peuples finno-ougriens. Études Finno-Ougriennes II. Fasc. 1. Paris: Klincksieck et al., pp. 35-68.

Lüko, Gábor. A zenei szimbólumok. Kézirat [Musical Symbols. Manuscript].

Munkácsi, Bernát 1893. Vogul népköltési gyujtemény III: 1: Vogul szövegek és forditításaik [A Collection of Vogul Folk-poetry]. Budapest: Magyar Tudományos Akadémia.

Nykysuomen sanakirja IV = Sadeniemi, Matti (ed. in chief) 1980. Nykysuomen sanakirja: Lyhentämätön kansanpainos 4: Nykysuomen sivistyssanakirja: Vierasperäiset sanat [Contemporary Finnish Dictionary]. Porvoo-Helsinki: Söderström.

Pekkilä, Erkki 1988. Musiikki tekstinä: Kuulonvaraisen musiikkikulttuurin analyysiteoria ja -metodi [Music as Text]. Acta Musicologica Fennica 17. Helsinki: Suomen Musiikkitieteellinen Seura.

Porthan, Henrik Gabriel 1983 (1st edition 1766). Suomalaisesta runoudesta [De Poësi Fennica]. Suomalaisen Kirjallisuuden Seuran toimitukisa 389. Helsinki: Suomalaisen Kirjallisuuden Seura.

Salve, Kristi \& Sarv, Vaike 1987. Setu lauludega muinasjutud [Setu Fairy-Tales with Songs]. Ars musicae popularis 5. Tallinn: Eesti Raamat.

SKSÄV IV/1 = Launis, Armas (ed.) 1910. Suomen Kansan Sävelmiä 4: 1: Inkerin runosävelmät [Finnish Folk Tunes 4: 1]. Suomalaisen Kirjallisuuden Seuran toimitukisa 68: 4: 1. Helsinki: Suomalaisen Kirjallisuuden Seura.

SKSÄV IV/2 = Launis, Armas (ed.) 1930. Suomen Kansan Sävelmiä 4: 2: Karjalan runosävelmät [Finnish Folk Tunes 4: 2]. Suomalaisen Kirjallisuuden Seuran toimitukisa 68: 4: 2. Helsinki: Suomalaisen Kirjallisuuden Seura.

Tedre, Ülo \& Tormis, Veljo 1975. Regilaulik [Textbook of Runic Songs]. Tallinn: Eesti Raamat.

Väisänen, Armas Otto 1937. Wogulische und ostjakische Melodien. Suomalais-Ugrilaisen Seuran Toimituksia 73. Helsinki: Suomalaisugrilainen Seura.

Vikár, László \& Bereczki, Gábor 1971. Cheremis Folksongs. Budapest: Akadémiai Kiadó. 